\title{
TINJAUAN HUKUM TERHADAP ITIKAD BAIK DALAM PERJANJIAN JUAL BELI TANAH
}

\author{
Ashar Sinilele \\ Universitas Islam Negeri (UIN) Makassar \\ Email : AsharSinilele@gmail.com
}

\begin{abstract}
In article 1338 of the Civil Code of paragraph 3, namely: "An agreement shall be executed in good faith." A treaty at the commencement of the implementation of the treaty and at the time of execution of the original agreement, especially in the case of land sale agreements, parties who are wellmeaning and act honest and compliance with applicable rules, must receive fair treatment and protection of the law by not forgetting the purpose of the rule of law in order to create a balance between the various interests concerned Keywords: good faith, buying and selling land

Abstrak

Dalam pasal 1338 KUH Perdata ayat 3, yaitu : "Suatu perjanjian harus dilaksanakan dengan itikad baik." Suatu perjanjian pada waktu dimulainya pemberlakuan perjanjian maupun pada waktu pelaksanaan perjanjian jula-beli terutama dalam hal perjanjian jual-beli tanah, pihak yang beritikad baik dan bertindak jujur serta berkepatuhan akan aturan yang berlaku, haruslah mendapat perlakuan dan perlindungan hukum yang seadil-adilnya dengan tidak melupakan akan tujuan dari peraturan hukum tersebut agar tercipta keseimbangan antara berbagai kepentingan yang bersangkutan
\end{abstract}

Kata kunci : itikad baik, jual-beli tanah 


\section{PENDAHULUAN}

$\mathrm{P}$ erkembangan sejarah bagi kehidupan umat manusia yang begitu pesat menyebabkan terjadi perubahan tentang apa yang dimaksud sebagai hukum dari masa ke masa sebelum manusia mengenal undang-undang, hukum tentu saja identik dengan kebiasaan dan tradisi yang menjadi pedoman dalam kehidupan mereka.

Melihat fenomena sekarang, perubahan-perubahan yang terjadi pada masyarakat di dunia dewasa ini merupakan gejala normal. Pengaruhnya bisa menjalar dengan cepat kebagian-kebagian dunia lain berkat adanya komunikasi modern.

Masyarakat pada umumnya sudah sejak dahulu mengenal sistem tukarmenukar barang dan jasa. Seiring dengan perkembangan kehidupan masyarakat yang makin maju dewasa ini dan kebutuhan yang semakin luas dan beraneka ragam, maka sangatlah diharapkan adanya kepercayaan diantara sesama karena kepercayaan merupakan salah satu faktor pendorong dalam dunia perdagangan dan kehidupan perekonomian khususnya dalam hal perjanjian.

Berbagai macam perjanjian telah dilaksanakan oleh umat manusia baik diatur dalam undang-undang maupun tidak diatur dalam undang-undang yakni perjanjian yang timbul dalam praktek sehari-hari.

Pada buku III tentang Perikatan, menurut pasal 1233 KUH-Perdata bahwa semua ikatan timbul dari suatu perjanjian atau dari undang-undang. Ikatan yang timbul dari undang-undang menurut pasal 1352 KUH-Perdata, timbul dari undang-undang saja atau dari undang-undang karena perbuatan manusia. Pasal 1352 KUH-Perdata menentukan bahwa ikatan yang timbul dari perbuatannya manusia.

Pasal 1338 KUH-Perdata dimaksudkan bahwa setiap perjanjian mengikat kedua belah pihak dan dapat ditarik kesimpulan bahwa orang leluasa untuk membuat perjanjian apa saja asal tidak melanggar ketertiban umum dan kesusilaan. Dengan kata lain, bahwa kedua belah pihak harus mempunyai itikad baik dalam mengadakan perjanjian agar tidak merugikan satu sama lain, sebagaimana yang diterangkan dalam pasal 1338 KUH-Perdata ayat 3, yaitu : "Suatu perjanjian harus dilaksanakan dengan itikad baik".

Kajian yang berhubungan dengan itikad baik dalam perjanjian jual beli dirasa amat kurang terutama dalam hak perjanjian jual-beli tanah sementara didalam praktek pelaksanaan perjanjian sering kali timbul berbagai kepincangan yang disebabkan adanya pihak-pihak yang beritikad buruk dalam persetujuan hanya untuk menguntungkan kepentingan-kepentingan pribadi sehingga menimbulkan kerugian-kerugian bagi pihak lain yang beritikad baik. 
Dalam lingkungan masyarakat pada umumnya sering terjadi kasus sengketa antara pemilik tanah antara satu dengan yang lainnya, yakni :

1. Dalam satu tanah sering didapat kepemilikan ganda, maksudnya pihak yang satu punya akte atas dirinya tetapi pihak yang lain juga mengklaim kalau tanah tersebut juga miliknya dan hal ini umumnya dapat mereka buktikan;

2. Disamping itu, sering juga terjadi kasus persengketaan mengenai tanah warisan yakni salah satunya pengambil alihan hak secara tidak sah atas bagian-bagian tanah waris anak-anaknya oleh saudaranya yang lebih tua karena itikadnya yang tidak baik;

3. Pemalsuan surat-surat pemberian hak (sertifikat);

4. Pemalsuan tanda-tangan; dan

5. Penyerobotan hak orang lain, serta lain sebagainya.

Maka dari itu pelegalan dari kepemilikan tanah sangatlah diharapkan agar dapat menghindarkan terjadinya sengketa.

Dalam masyarakat masih sering kita jumpai adanya pihak yang tidak beritikad baik/tidak jujur dalam melaksanakan perjanjian jual-beli sehingga pihak yang menjadi korban akibat dari ketidak jujuran tersebut akan merasakan pahit getirnya.

\section{PEMBAHASAN}

\section{A. Perlindungan Hukum yang Beritikad Baik Dalam Perjanjian Jual Beli tanah}

Sebagaimana dalam Pasal 1338 ayat 3 KUH Perdata, menyatakan bahwa suatu perjanjian harus dilaksanakan dengan itikad baik. Itikad baik pada waktu membuat suatu perjanjian berarti kejujuran, maka itikad baik dalam tahap pelaksanaan yaitu, perjanjian adalah kepatutan yaitu suatu penilaian terhadap tindak tanduk suatu pihak dalam hal melaksanakan apa yang diperjanjikan. Sehingga dapat memberi kepastian hukum mengenai isi perjanjian yang tidak selalu dinyatakan dengan jelas. Dengan demikian, itikad baik (niat yang tulus disertai dengan kejujuran) dan kepatuhan merupakan hal yang amat penting dalam melaksanakan perjanjian dan hal ini sangatlah perlu diterapkan terutama dalam perjanjian jual-beli tanah.

Itikad baik pada saat mulai berlakunya suatu perjanjian lazimnya berupa perkiraan dalam hati sanubari yang bersangkutan. Disinipun itikad baik terletak pada keadaan jiwa manusia akan tetapi tidak selalu tercermin pada tindakan yang dilakukan oleh kedua belah pihak dalam hal ini melaksanakan janji. 
Pembayaran merupakan pelaksanaan jual-beli dalam arti sebenarnya yaitu bahwa dengan pembayaran ini maka tercapailah tujuan perjanjian jual-beli secara yang tergambar dalam alam pikir kedua belah pihak pada waktu membentuk persetujuan. Dari cara pemusnahan, perjanjian dapat disamakan dengan pembayaran, oleh karena perbedaan hanya terletak pada tidak bersedianya pihakpihak untuk menerima suatu pembayaran, akan tetapi penerimaan ini dapat dikatakan bahwa tujuan perjanjian adalah tercapai.

Pembayaran dari harga suatu barang yang diperjualbelikan itu harus dilakukan di tempat yang ditetapkan dalam persetujuan. Jika dalam persetujuan tidak ditetapkan suatu tempat, maka pembayaran itu yang mengenai suatu barang yang sudah ditentukan, harus terjadi di tempat dimana barang itu berada sewaktu persetujuan dibuat.

Niat yang tulus disertai dengan kejujuran terletak pada keadaan jiwa manusia akan tetapi tidak selalu sifat ini terletak pada tindakan yang dilakukan oleh pihak yang bersangkutan dalam hal melaksanakan ikatan janji, dan diharapkan anggota masyarakat yang bersangkutan menjauhi sifat merugikan pihak lain (beritikad buruk).

R. Subekti, ${ }^{1}$ berpendapat bahwa : perlu dicantumkan suatu ketentuan yang menyatakan bahwa apabila suatu perjanjian dilakukan dimuka suatu Pejabat, maka para pihak dapat dianggap beritikad baik.

\section{B. Akibat Hukum dalam Perjanjian Jual-Beli tanah yang Tidak Beritikad Baik}

Dalam perjanjian jual-beli terkhususnya jual-beli tanah sangatlah diharapakan dapat tercipta keseimbangan antar kedua belah pihak yang bersangkutan, salah satunya itikad baik antar sesama yang juga diharapkan dapat tercipta suasana yang kondusif.

Menurut pasal 1362 KUH Perdata dan pasal 1383 KUH Perdata dibedakan antara ada atau tidaknya itikad baik dipihak yang menerima pembayaran. Pasal 1360 KUH Perdata, menyatakan bahwa siapa yang dengan itikad baik, telah menerima sesuatu yang tidak harus dibayarkan kepadanya, diwajibkan mengembalikan dengan bunga dan hasil-hasilnya, terhitung dari hasil pembayaran dan demikian itu tidak mengurangi penggantian biaya, rugi dan bunga, jika harganya telah menderita kemerosotan. Jika barangnya telah musnah, meskipun ini terjadi diluar salahnya, maka ia wajib membayar harganya dengan disertai penggantian bunga, rugi dan harga, terkecuali jika ia dapat membuktikan bahwa

${ }^{1}$ R. Subekti, Aneka Perjanjian (Cetakan IV, Alumni Bandung: 1984), h. 74 
barang itu musnah juga, seandainya ia berada pada orang kepada siapa ia seharusnya diberikan.

Tidak beritikad baiknya suatu subjek hukum juga dapat menyebabkan terjadinya perbuatan melanggar hukum, seperti diatur dalam pasal $1365 \mathrm{KUH}$ Perdata yang sangat penting sekali dalam lalu lintas hukum.

Pasal 1365 KUH Perdata, berbunyi : "Tiap perbuatan melanggar hukum, yang membawa kerugian pada orang lain, mewajibkan orang yang karena salahnya menimbulkan kerugian itu, mengganti kerugian tersebut".

Begitu pentingnya pasal $1365 \mathrm{KUH}$ Perdata sehingga pasal tersebut digunakan untuk menuntut masalah perdata yang menyangkut materi hukum lainnya, seperti tanah, perumahan, merek cipta. Terutama berkaitan dengan kepentingan yang didasari dengan tidak beritikad baik.

Menurut pasal 1363 KUH Perdata : apakah si penerima barang ini adalah beritikad baik dan kemudian sudah ataukah siapa yang telah menjual barang sesuatu yang diterimanya dengan beritikad baik sebagai pembayaran hak usahlah ia mengembalikan sesuatu apa.

Jika dalam penjualan sebuah benda tak bergerak, terjadi dengan menyebutkan luas dan isinya, dengan ditentukan suatu harga menurut ukurannya, maka sipenjual diwajibkan meyerahkan jumlah yang dinyatakan dalam persetujuan. Dan jika sipembeli tidak menuntutnya, maka sipenjual harus bersedia menerima suatu pengurangan harga menurut imbangan.

Sehingga dengan demikian penulis menyadari bahwa, para pemegang hak atas tanah harus taat kepada kewajiban atau keharusan untuk mendaftarkan haknya kepada yang berwenang baik demi kepentingan masa kini maupun yang akan datang (keturunannya), selain untuk mencegah itikad-itikad tidak baik juga untuk membantu atau memperlancar kepentingan si pemegang hak yang sah dalam hal memperoleh pinjaman-pinjaman dari pemerintah dan atau pembebanan hak-hak lainnya atas tanah seperti hipotek dasn crediet verband, hak guna bangunan didirikan atas tanah. Demikianlah tentang manfaat-manfaat dari pendaftaran tanah.

Pembayaran yang berakibat pembebasan pihak berutang dapat dilakukan oleh setiap orang yang mempunyai kepentingan dalam hal pembayaran ini, seperti pada pembayaran jual-beli tanah di notaris dikenal dengan istilah prajual-beli, dalam artian bahwa pembeli belum melunasi. Misalkan total harga perjanjian 100 juta rupiah tetapi pembeli baru membayar setengah harga dari perjanjian yang ditetapkan dan berjanji bahwa nanti tanggal sekian akan melunasi, maka mereka masuk perjanjian pengikatan jual-beli. 
Dan didalam perjanjian jual-beli tanah dikenakan pajak, jika pembayaran dibawah 60 juta rupiah, maka dikenal istilah bagi penjual yakni BPHTP (Bea Perolehan Hak Atas Tanah dan Bangunan) atau SSB dan jika pembayaran diatas 60 juta rupiah, maka dikenal istilah bagi pembeli yakni PPh (Pajak Penghasilan).

Jadi, sebelum terjadi jual-beli terutama dalam hal jual-beli tanah, maka sertifikat harus dicek terlebih dahulu di Kantor Pertanahan agar nanti pihak notaris dan PPAT tidak mendapat masalah dikemudian hari dan perlunya menganalisa mengenai data-data dari pihak penjual, serta pembeli harus berhatihati dalam melaksanakan perjanjian jual-beli terutama dalam hal jual-beli tanah termasuk menghindarkan diri dar perangkap mafia tanah.

Perlu diketahui bahwa orang yang membayar itu pemilik mutlak objek yang akan dibayarkan dan juga berkuasa memindah tangankannya, agar pembayaran yang dilakukan itu sah. Meskipun demikian, pembayaran suatu jumlah uang atau suatu barang lain yang dapat dihabiskan, tidak dapat diminta kembali dari seorang dengan itikad baik telah menghabiskan barang yang telah dibayarkan itu. Sekalipun pembayaran itu telah dilakukan oleh orang yang bukan pemilik atau orang tak cakap mengasingkan barang tersebut. Pembayaran harus dilakukan kepada si berpiutang, atau kepada orang yang dikuasakan olehnya, atau juga kepada orang yang dikuasakan oleh hakim atau oleh undang-undang untuk menerima pembayaran-pembayaran bagi si berpiutang.

Pasal 1386 KUH Perdata memuat kekecualian lain lagi terhadap tidak sahnya pembayaran kepada orang lain dari pada pihak-pihak sendiri, yaitu apabila pembayaran dilakukan secara jujur/beritikad baik kepada seseorang, yang bertindak seolah-olah sebagai pihak yang berhak menerima pembayaran. Dalam hal ini surat tanda utang yang dapat dioperkan kepada orang lain, seperti wesel yang memberi kepada sipemegang ini mudah dianggap sebagai yang benar-benar berhak, sedangkan pemegang tanda utang itu mungkin mendapatkannya dengan cara melanggar hukum, harus mengira bahwa hal memegang tanda utang itu terjadi secara sah menurut hukum atau pada umumnya seseorang yang bertindak sebagai pihak itu memang pihak sejati.

Hal ini juga dapat dilihat dalam pasal 9 UUPA No. 5/1960 berkaitan pendaftaran tanah dimaksudkan untuk menjamin kepastian hukum demi diterjaminnya ketertiban dalam masalah pertanahan. Mengingat karena hak atas tanah tidak selamanya tetap melekat pada sipemegangnya karena adanya pemindahan yang disebabkan kepentingan-kepentingan mereka yang bersangkutan.

Sebagai hukum, UUPA tidak hanya mengatur tentang hak seseorang atas tanah yang diwenangkan sebagai miliknya, diwenangkan untuk diguna usahakan 
olehnya atau diluangkan untuk didirikan bangunan-bangunan sejenisnya atau lainlain tetapi mengatur juga tentang kewajiban-kewajiban si orang yang bersangkutan sehingga pendaftaran tanah sangat diharapkan tanpa menimbulkan kerugian-kerugian pada kepentingan orang lain dan masyarakat baik karena itu disebabkan dari itikad buruk dari subjek hukum.

\section{PENUTUP}

sebagaimana dalam pasal 1338 KUH Perdata dimaksudkan bahwa setiap perjanjian mengikat kedua belah pihak. Dan dapat ditarik kesimpulan bahwa orang leluasa untuk membuat perjanjian apa saja asal tidak melanggar ketertiban hukum dan kesusilaan. Dengan kata lain, bahwa kedua belah pihak harus mempunyai itikad baik dalam mengadakan perjanjian agar tidak merugikan satu sama lain, sebagaimana yang diterangkan dalam pasal 1338 KUH Perdata ayat 3, yaitu : "Suatu perjanjian harus dilaksanakan dengan itikad baik." Dimulainya suatu perjanjian pada waktu dimulainya pemberlakuan perjanjian maupun pada waktu pelaksanaan perjanjian jula-beli terutama dalam hal perjanjian jual-beli tanah, pihak yang beritikad baik dan bertindak jujur serta berkepatuhan akan aturan yang berlaku, haruslah mendapat perlakuan dan perlindungan hukum yang seadil-adilnya dengan tidak melupakan akan tujuan dari peraturan hukum tersebut agar tercipta keseimbangan antara berbagai kepentingan yang bersangkutan 


\section{DAFTAR PUSTAKA}

Amiruddin, dkk. 2004. Pengantar Metode Penelitian Hukum. PT. Raja Gratindo Persada : Jakarta.

Abdulhay Marhainis, 1982. Hukum Perdata Material. PT. Pradnya Paramita.

Effendi Perangin. Hukum Agraria di Indonesia Suatu Telaah dari Sudut Pandang Praktisi Hukum, Rajawali, Jakarta, 1989, h. 195 jakarta 1985, Praktek Jual-Beli Tanah. PT. Raja Grafindo Persada,

Hartono Soerjopratiknjo, 1994. Aneka Perjanjian Jual-Beli. PT. Mustika Wikasa, yogyakarta.

Urip Santoso, 2007, Hukum Agraria dan Hak-Hak Atas Tanah. Kencana Prenada Media Group : Jakarta

----------, 2005, Undang-Undang Pokok No. 5 Tahun 1960 Tentang Pertaturan Dasar Pokok-Pokok Agraria. Kencana Prenada Media Group : Jakarta

Salim, H. S. Hukum Kontrak - Teori dan Teknik Penyusunan Kontrak. Sinar Grafika. Jakarta.

R. Subekti, 1984, Aneka Perjanjian, Cetakan IV, Alumni Bandung. -, 1985, Pokok-Pokok Hukum Perdata. PT. Intermasa : Jakarta

-------------, 1993, Perbandingan Hukum Perdata. Pradnya Paramita : Jakarta.

------------, 1996, Pokok-Pokok Hukum Perdata. PT. Intermassa : Jakarta.

R. Soesilo. 2007. Kitab Undang-Undang Hukum Perdata. Wipres.

R. Soerjatin. 1983. Beberapa Soal Pokok Hukum Perdata dan Hukum Dagang Pradnya Paramita : Jakarta.

R. G. Kartasapoetra. 1985. Hukum Tanah - Jaminan UUPA Bagi Keberhasilan Pendayagunaan Tanah. PT. Bina Aksara : jakarta.

Soerjono Soekanto, 1986. Pengantar Penelitian Hukum. Universitas Indonesia Salemba.

Kansil, dkk. 2006. Modul Hukum Perdata termasuk Azas-Azas Hukum Perdata, PT. Pradnya Paramita : Jakarta.

Wirjono Prodjodikoro, 1973. Azas-Azas Hukum Perjanjian. Sumur Bandung. Sumur Bandung. 1990 Azas-Azas Hukum Perdata. PT. Bali Bandung. 